\title{
The role of psychology in enhancing public policy: Studies on political apathy and attachment to the city in Indonesia
}

Anindya, Shafira

Department of Psychology, Bina Nusantara University, Indonesia (shafira.nin@gmail.com)

Leolita, Vemmy

Department of Psychology, Bina Nusantara University, Indonesia (champaignev@yahoo.com)

Abraham, Juneman

Department of Psychology, Bina Nusantara University, Indonesia (juneman@binus.edu)

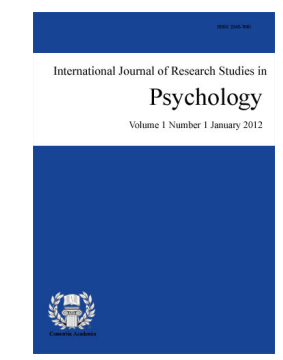

ISSN: $2243-7681$ Online ISSN: 2243-769X

OPEN ACCESS

Received: 1 October $2014 \quad$ Revised: 11 November $2014 \quad$ Accepted: 27 November 2014 Available Online: 28 November 2014 DOI: $10.5861 /$ ijrsp. 2014.922

\begin{abstract}
The author conducted two studies with predictive correlational designs aiming to contribute understanding on socio-psychological dynamics related to public participation in public activities. This study applied purposive sampling and multiple linear regression data analyses. The first study with participants of 214 University of Indonesia students found that the sense of citizenship as well as indecision dimension of decision fatigue in taking political decision played a role in predicting public political participation in students. The second study with participants of 230 participants from urban music communities in Jakarta and its surroundings as well as in Bali, Indonesia, found that trust in municipal government has a negative correlation with attachment towards city and that participation in urban music communities does not contribute to such attachment. These results provided insights that we need to study the society psychosocial reality further, as one of the fields of the battle ground of interpretations of public policy, in order to increase the efficacy of public policy.
\end{abstract}

Keywords: public; policy; fatigue; attachment; citizenship 


\section{The role of psychology in enhancing public policy: Studies on political apathy and attachment to the city in Indonesia}

\section{Introduction}

Public policy is "all those individuals who see their interests and purposes as being related to and affected by (positively or negatively) ... that in some form is intended to be the basis for legislation or administrative actions ... in terms of conceptions of how life should be lived and organized in the society" (Sarason, 1984, p. 199). Abidin (2012) stated that an object of government intervention or public policy can only be understood and comprehended by society in a specific time and environment; and that policy can be reviewed with one or more scientific approach, including psychological approach. Research-based scientific approach is required because in the future, we need further evidence-based policy thus enabling best decision making (McKnight, Sechrest, \& McKnight, 2005).

Gittins (2012) highlighted the sub-discipline of public policy psychology, and stated that psychology provides a robust framework regarding decision making in the context of forecasting or policy-testing. Psychology is successful in showing that human behavior is not always able to be mapped out using rationalistic model; or in other word, human behavior can be emotional. Human behavior can also raise unintended consequences (Gittins, 2012; McKnight et al., 2005). One of the implications is, "When people are not rational, it is not rational to assume they are when designing policy" (Gittins, 2012, p. 380). This reality shows that psychology is needed in order for the design and implementation of public policy can truly be efficient, effective, adequate, fair, and appropriate. This is so because the understanding of the dimensions of human behavior which are mostly obtained from psychology will be very useful in formulating public policy—which also has many dimensions in connection with humanity (Sirgy, 2008).

In the relation between psychology and public policy, there are several issues that must be observed such as the following (Brayfield, 1967; Fischhoff, 1990; Heinowitz et al., 2012; McKnight et al., 2005; Strickland, 1996): First, psychological research —of which the results are utilized as materials in formulating public policy-can be performed by anyone, not solely by psychologist. Second, the knowledge and training possessed by psychologists in (1) measurement, (2) research methodologies and (3) intervention are actually beneficial to psychologists in conducting quality policy analysis and evaluation. However, generalization of psychological science and practice to social axes is often neglected by psychologist thus the contribution of psychology toward public policy is not that much articulated and recognized. Third, public behavior can threaten (meaning: not supporting) a public policy which was initially believed or viewed favorably for public interest. This matter can create urgency for inviting psychologist to transform public attitude, although a psychologist must be aware of the political interest involved in the process. Fourth, public policy is often presented as a black-or-white issue, whereas psychologist tends to work on issues in the "gray area". Fifth, psychology as a science and profession, in addition to being able to influence the political process and public policy, can in reverse to also be influenced by them. Sixth, psychology as a profession has its own unique epistemology differentiating it from other professions that are also trying to influence legislation (lawyer, businessman, etc). For example, psychology helps legislator from being trapped in cost-benefit consideration in formulating legislation, and also to consider citizen satisfaction and well-being.

In relation to the fifth and sixth point above, this study attempt to answer two issues relating with involvement of psychology—specifically social psychology—in the context of public policy. First, what are some psychological variables that can predict political participation of college students? Political participation is needed to change the condition of society towards a more prosperous future (Abraham \& Viatrie, 2013), and this objective is in line with the goal of public policy in general. Second, what is the role of some psychological variables in predicting attachment of citizens to their city? Attachment of citizens to their city is assumed as a 
The role of psychology in enhancing public policy: Studies on political apathy and attachment to the city

pre-requirement in facilitating an effective implementation of public policy.

Furthermore, there is a fundamental reason why both (political participation and city attachment) are chosen as dependent variables of this study in the context of public policy. Public policy variables that are highlighted in this study are not in the form of regulation that must be obeyed. However, the main focus of this study in relation to public policy is the moral substance of political participation and attachment to the city. The author believes that public policy in the form of rule or law may change from time to time. However, the pivotal thing underlying the form is the guarantee of the inclusion of moral substance which is in line with the fundamental moral intuition of citizens (Munger, 2011). Study of this issue is more vital than study of adherence to fixed or specific explicit regulation. If the predictors of political participation (or apathy) and attachment to the city are known, then psychologist can play a role in eliminating barriers to as well as advocating increment of such participation and attachment.

This research consisted of two studies. The hypothetical models are visualized in Figure 1.
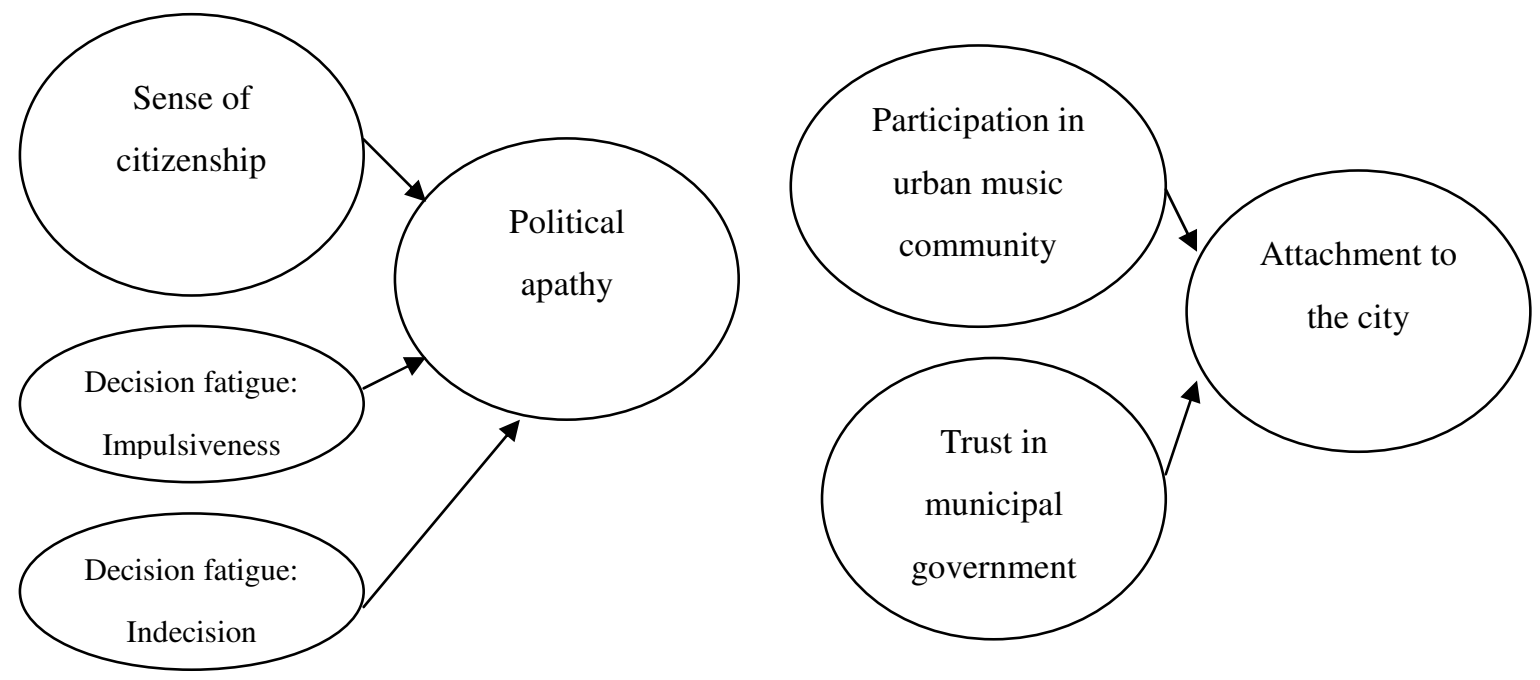

Figure 1. Hypothetical models (left: Study 1; right: Study 2)

\subsection{Study 1-Political Apathy: Rationale}

Political apathy is the opposite of political participation. Political apathy is a worrying psychosocial phenomenon among college students because, as part of the middle class, students are "the conscience of the people". They are expected to carry out positive changes in the society, but lots of them stay away from the most effective means for the purpose-namely politics (Abraham \& Viatrie, 2013). There are three key variables affecting political participation of student, namely personality, sociocognitive variables, and psychodemographic variables (Abraham \& Viatrie, 2013).

This study contributes by employing sense of citizenship and decision fatigue-which are parts of sociocognitive variables-as predictors of political participation or apathy. Sense of citizenship is a psychological feeling of attachment in the form of awareness as a citizen to improve the public life quality and the public virtue (Muluk, 2010). Lack of sense of citizenship is assumed to have implication on the lower spirit to improve public area and life, low political participation, even higher spirit to destroy public life (such as corruption). Muluk (2010, p. 19) confirmed that low sense of citizenship will affect public policy process as follows: "Public policy cannot function as it should: the formulation process was ill-advised from the beginning, the decision making process is biased of interest, and the implementation on the field is chaotic." Hence, it is 
logical to hypothesize the existence of negative correlation between sense of citizenship and political apathy.

Decision fatigue is syndrome of avoidance toward decision-making caused by (1) difficult and costly data (as decision-making material) collection process; (2) perception about the lack of efficacy in performing complex analysis of data or available options, usually because of the many alternatives (choice overload), followed by dilemmatic or difficult decision, or because people have to make repetitive decisions; (3) perception about uncertainty of source or material of decision-making (Nicholson, 2007). In voting during the election, symptoms of decision fatigue culminate in (1) abstaining or not using the right to vote; (2) letting others decide which political candidate to choose, and (3) taking decision shortcuts or heuristics, by choosing political candidates that have been chosen previously (status quo), or choosing a candidate who is on the number 1 position on the ballot, or choosing a candidate based on gender or ethnicity (Augenblick \& Nicholson, 2012; Nicholson, 2007). Symptom number (1) is related to indecision. Symptom number (2) and (3) are related with impulsiveness. Impulsiveness in decision-making occurs if the required resources for decision-making are depleted and this causes a faster decision-making; an individual experience ego depletion (Vohs et al., 2008). Indecision occurs if an individual is reluctant to process or find more information hence resulting in abstention or avoiding choices.

Either consecutive decision-making or a decision-making that involves a high and continuous load of information processing has a "biological price" (Tierney, 2011). The mental energy spent from one process to another makes it more difficult for the brain to determine the choice, and, as the result, the brain tries to find shortcuts. As stated, there are two types of shortcut that can be taken (Tierney, 2011), namely "just do it" (without thinking of the consequences; impulsiveness), and not doing anything (indecision). Both in essence save mental energy. The two psychological conditions could predict political apathy because apathy is in line with the saving. Apathetic action can be seen as a strategy to relax the tension (reducing fatigue) in the "struggle" for mental energy. Thus, it is logical to hypothesize that the dimensions of decision fatigue correlate positively with political apathy.

\subsection{Study 2-Attachment to the City: Rationale}

Communities that no longer have a sense of ownership of their city, that have been alienated from their own city, and that imagine of staying at another place, are some phenomena that are generally found today. Problems of transportation, health, housing, crime; decreased social solidarity; conflict and violence between citizens; flood and fire; the loss of cultural site and heritage; poor public facilities and services as well as the lack of guarantee to earn a decent living; are problems that are usually found in cities in Indonesia and exacerbate the above conditions (Ancok, 2004; Wunas, 2011). Problems of the natural environment complexly interact with socio-cultural problems in the city.

However, there are facts that a city such as Jakarta also paradoxically provides hope. For example, first, in a city, poverty exist side by side with wealth, destruction exists side by side with innovation, exclusivity with inclusivity, thanatos (the death instinct) side by side with eros (the life instinct), lamentation side by side with glorification, pollution side by side with hope of ecological integrity (Herry-Priyono, 2009). Second, for city residents with Indonesian culture, a person's worth is not solely determined by his/her job. Consequently, a person that does not find a job does not necessarily means he/she is despicable because there are other social parameters used in judging a human being, and if there is a will, a person can always survive in a city (Magnis-Suseno, 2009). Third, city residents have the potential for mutual consciousness to struggle for democracy, as well as relentless responses to issues surrounding the action of Government or capital owners, which is realized through activities in public space, piazza, or square (Supelli, 2009; Sutrisno, 2009). Fourth, sociality in the city actually does not disappear, but rather it is in a process of finding new forms in the context of change in city space and modes of communication in cyberspace networks (Hardiman, 2009).

Based on the above reality, it is intriguing to examine factors that can predict attachment of a person to 
his/her city. The first variable for predicting attachment is the level of participation of resident in urban music communities. Urban music community is an icon of activity in a city. It is in line with the statement, "A city is owned not by the government but by people who do things in it" (Biggs as cited in BCCF, 2011). Gardner (2010) stated that music has the potential to build as well as drive meaningful social relationships and action. "The subcultures, scenes, and communities that individuals build collectively around music activities become sites of memory, identity, and cultural expression" (Gardner, 2010, p. 72). By using symbolic interactionism perspective, participation in urban music community can be viewed as an activity that include exchange of social practices and shared code among its members that affect the individual's daily lives. The intimacy and trust formed in the community can create meaning of life for its members, in which the meaning of life can experience generalization to the context of citizens' living in a city where the music community live and grow. Nowotny et al. (2010) stated that through participation in music community, people obtains a comprehensive understanding of self, culture, and identity, as well as shapes them. Interaction that occurs in the community can maintain local culture and create a sense of place as well as individual relationships with the collective (Nowotny et al., 2010; Schneider, 2009).

In a preliminary study, the author interviewed several music communities in Jakarta and Bali area. In Jakarta, the author visited one of its parks in July 2013. The park is usually a place of gathering for people who play music. The author had a chance to interview several community members related to how they feel toward the city. The majority of those who are natives of Jakarta said that they felt less attached to the city or feel less comfortable living in the city. They felt so because of traffic jam and floods that continuously hit the capital. The minimum performance of government is suspected as the main cause of why there is no solution to the traffic jam and floods up to now. The lack of public facilities, such as bus stops that are not well maintained, garbage scattered everywhere, streets that are not paved are also factors which cause the people of Jakarta to be less attached to their city. Whereas, a minority of those who are not natives of Jakarta said that they feel rather comfortable living in Jakarta. Their purpose of coming into the city is to find work. Thus they feel comfortable living in the capital because they are of the opinion that Jakarta has many job opportunities, and from that job they are able to have sufficient incomes to support themselves and their families (for those who are married). However, their complaints are not much different from the majority of the natives of Jakarta, namely traffic jam, floods, and the lack of public facilities.

In Bali, the author in March 2013 interviewed traditional musical instrument (such as gamelan) players who joined Bali traditional music communities in Denpasar, Ubud, and Singaraja regarding the same issues. They really love their cities. The cities are viewed as having a strong culture that must be preserved. They are proud of and feel attached to the cities. Bali annually brings in many tourists, both local and foreign, and in those moments, they have the opportunities to introduce Bali's culture to tourists, while simultaneously preserving it. They are also proud of the local government that has made a major contribution to the preservation of culture, especially gamelan performance. The local government is also considered able to provide proper public facilities even though they are not as complete as in Jakarta. However, it is not really a problem. For the communities, the government of Bali has performed well by contributing in preserving Bali's culture. In addition, they also consider Denpasar, Ubud, and Singaraja as relatively clean and comfortable cities to live in. However, they are not so when the holidays arrive. Garbage is scattered everywhere, especially in the beach area.

When the author had a chance to interview members of the music communities in Jakarta and Bali, the author also asked regarding forms of participation that they did in their communities. The music community in Jakarta consists of several individuals participating in musical activities for one purpose that is to entertain the people coming to the park. They do not only play music, but also exchange musical knowledge, thus eliminating barriers between them. In addition, citizens around are welcomed to join in playing musical instruments and learning music in the park. In the urban music communities, there is a vast opportunity for intensive information exchange about the city, discussion of the fate of the city, discussion of the history and the growth of the city (past, present, and future), and for creating plans for the city regarding what can be done for the advancement of the city. All of these things are predicted to bring attachment to the city. 
In Bali's cities, gamelan community members said that the social motive to participate in musical community is the deep sense of obligation in the Balinese to play musical instruments for certain ceremonies in Bali, as well as to introduce Indonesian traditional music so it can be viewed equally with Western music. For Balinese, community has an important significance. There are many positives arising from performing in the community, such as freely expressing imagination, creating new works with constructive messages, and motivating people with the works. Art has a significant meaning for Balinese because it channels their passion by creating art works that can be consumed by the general public, as well as preserves Bali's culture such as dances and music. Various activities conducted by members of the Bali's urban music communities are believed to make them become attach to their city.

The second variable in predicting attachment to the city is trust in municipal government. On the interpersonal and organizational level, relationship between these two constructs (trust and attachment) has been found empirically. On the interpersonal level, Fuller and Fincham (1995) showed empirical support on their hypothesis which stated "Spouses who become more trusting of their partner will be more secure, less ambivalent, and less avoidant ... than spouses who become less trusting of their partners" (p.21). Tyas, Yuniarti, and Kim (2012) found that trust shapes the relation between parent and child. On the organizational level, trust in the organization and its leadership correlate positively with various forms of attachment toward organization. The explanation is that the trust causes satisfaction in a relationship with the organization, and make people who trust willing to maintain the relation and. In line with social exchange perspective, the positive things they gain from the trust make them reluctant to find other alternative relationship; while distrust undermine the cohesion of the group (Thau et al., 2007). In this research, both of those findings are transferred to social axis, thus resulting in conjecture that trust toward municipal city government will correlate positively with attachment to the city.

\section{Methods}

\subsection{Study 1}

There were 214 participants (77 males, 137 females) of the field study, with an age range of 17-23 years old (mean of age $=19.63$ years old; standard deviation of age $=1.584$ years old) taken using purposive sampling technique. Participants of the pilot study for instrument tryout were 90. All participants involved are college students, with a composition of the student studying in their 1st-5th semester as many as 119 students, and 95 students studying in 6th semester. The top three study programs of participants are Accounting (27 students), Psychology (20 students), and Law (17 students). As many as 52 students admitted of being in close association with nationalist political parties; 15 students admitted of being in close relation with religious parties, and 147 students admitted of not being in close association with either party. A predictive correlational design is utilized to conduct this study. The data is analyzed using multiple linear regression analysis.

Measurement instrument of sense of citizenship is adapted from Global Citizenship scale (Morais \& Ogden, 2011) and translated into Indonesian. However, global coverage in the original scale is changed into national and local coverage, as well as classified based on three dimensions of sense of citizenship, namely social responsibility, competence, and civic engagement. Social responsibility is an individual's perception regarding the interdependence relationship between him/herself and others. It also refers to his/her level of concern or caring for others, society, and the environment. Individual with high social responsibility understands that his/her action has a social consequence. Competence is an attribute of owning an open mind as well as an effort to understand socio-cultural norms and expectations. Those virtues are channeled to work effectively with fellow citizens. Civic engagement is the act of recognizing local and national problems as well as responding to them through political activity and volunteerism in the community.

Examples of items of Social Responsibility dimension are "I respect and am concerned with the rights of all people in my country"; "No group of people should dominate and exploit others in this country"; "I do not feel 
The role of psychology in enhancing public policy: Studies on political apathy and attachment to the city

responsible for the nation's inequities and problems" (unfavourable item; response is reversely coded). Examples of items of Competence dimension are "I know how to develop a place to help mitigate a national environmental or social problem"; "I welcome working with people who have different cultural values from me". Examples of items of Civic Engagement dimension are "I will deliberately buy brands and products that are known to be good stewards of marginalized people and places"; "Over the next 6 months, I will volunteer my time working to help individuals or national communities." Response options of the scale range from Strongly Disagree (score of 1) to Strongly Agree (score of 6).

Measurement instrument of decision fatigue is constructed by the author based on two dimensions of decision fatigue, namely impulsiveness and indecision (Brokaw, 2011; Ferrari \& Pychyl, 2007). Impulsiveness is an individual act in choosing or deciding recklessly without considering the consequences that may occur. Indecision is an individual reluctance to use the resources available to him/her in processing multiple and/or conflictual choices, thus resulting in a delay of voting decision. An indecisive individual refused to grasp the required information in making an accurate decision among the many attractive alternatives.

Examples of items of impulsiveness are "I give my vote to the candidate with the most votes"; "My vote in the general election has been carefully thought through" (unfavorable item, reversely coded score). An example of items of indecision is "I rather not vote than vote carelessly". Response scale of the scale range from Strongly Disagree (score of 1) to Strongly Agree (score of 6).

Measurement instrument of political apathy is adapted from political participation scale (Abraham \& Viatrie, 2013). Examples of items in this instrument are: "I distributed petitions demanding quality improvement of government policy/regulation" (unfavorable item); "I use public facilities (road, building, park, etc) to perform social protest" (unfavorable item). Response scale of the scale range from Strongly Disagree (score of 1) to Strongly Agree (score of 6).

Validity and reliability test showed that measurement instrument of sense of citizenship has a good internal consistency index (Cronbach's Alpha) of 0.891 with construct validity index (corrected item-total correlations) ranging from 0.315 to 0.709 . There is a total of 23 items in this measurement instrument after reliability and validity testing. Measurement instrument of impulsiveness dimension of decision fatigue has a Cronbach's Alpha index of 0.698 , with corrected item-total correlations ranging from 0.298 to 0.514 . There is a total of 6 items in this measurement instrument after reliability and validity testing. Measurement instrument of indecision dimension of decision fatigue has a Cronbach's Alpha index of 0.857 , with corrected item-total correlations ranging from 0.298 to 0.762 . There is a total of 10 items in this measurement instrument after reliability and validity testing. Measurement instrument of political apathy has a Cronbach's Alpha index of 0.933, with corrected item-total correlations ranging from 0.298 to 0.694 . Alpha Index of more than 0.6 and corrected item-total correlations above 0.25 indicates that the measurement instruments are reliable and valid.

\subsection{Study 2}

There were 90 participants of the pilot study for instrument tryout. There were 230 participants (135 males, 95 females) in the field study ranging from 21-40 years old (mean of age $=26.83$ years old; standard deviation of age $=5.376$ years old) taken using purposive sampling technique. All participants are involved in the activity of urban music community. This study not only take those subjects who are proficient in playing music, but also those actively involved in making a decision within the music community as well as planning of specific goals for development of the music community. Participants of this study originate from Jakarta (165 participants: Suropati Art, Taman Suropati Chamber/TSC, etc), Bekasi (30 participants; Bekasi Jazz Community), and Bali (35 participants; Singaraja Gamelan Community, Denpasar Gamelan Community, Ubud Gamelan Community). Based on education level, there were 128 participants studying for Bachelor degree, 36 participants have Diploma degree, whereas 56 participants with high school and junior high school education, and 9 participants with no response in indicating their educational level. A predictive correlational design is chosen to conduct this 
Anindya, S., Leolita, V., \& Abraham, J.

study. The data is analyzed using multiple linear regression analysis.

Measurement instrument of Participation in the Activities of Urban Music Community is constructed by the author based on dimensions of participation in community activities (Campbell \& Jovchelovitch, 2000). The dimensions are as follows: First, participation in shared identity, where the community is articulated or actualized. Identity is constructed and reconstructed within the range of structural and symbolic limits that allow people to construct images about themselves which reflects their potential and interest. Participation is an act that organically relate with the consciousness of who and what is desired by the community. Identity can be shaped, renegotiated, even changed if necessary. Second, participation is a social representation that organizes the view regarding community members and guides the interpretation of daily reality and practice. In other word, participation relates with how a community builds local knowledge (regarding their own community) and sharing it. This knowledge representation can never be separated from concrete social, cultural, and historical context where the community grows and develops. Participation in community activity enables individual members to express, reaffirm, or negotiate that social representation. Third, participation in power, both toward resources and symbolic recognition. In this case, power is not considered as an intrinsic negativity, rather as a space of possible acts, where subjects socially fight for and express their influence. Through participation that interacts with power, people create influence, build reality, and build purpose for their community.

Participation in community activity is defined as implementing the three dimensions in the process where the community is actualized, negotiated, and transformed. Through participation in a community group, people develop an awareness of community resources and engage with significant others in the public arena.

Measurement instrument of Participation in the Activities of Urban Music Community has the following introduction: "The following are activities perform in an urban music community. Read the following statements, and specify how often you are involved in the following activities." This scale has five response options namely "Never", "Rarely", "Sometimes", "Often" and "Always". Examples of items in the instrument are: "Creating a plan together to voice aspiration of the community through musical performances", "Initiating or discussing the identity of the music community (vision/mission, sticker, chants, t-shirt, etc)", "Dissecting the uniqueness of local music", "Sharing of values with other members of the music community".

Measurement instrument of Attachment to the City is adapted by the author based on measurement instrument of place attachment, with the dimensions of attachment to physical/natural aspect of place and attachment to the social aspect of place (Raymond, Brown, \& Weber, 2010). Examples of items of this scale are "I am not proud of my city" (unfavorable item), "This city is special to me", "I respect things that are championed by my city", "The natural area of this city is special to me", "I am attached to the green area of this city". Response scale of the scale range from Strongly Disagree (score of 1) to Strongly Agree (score of 6).

Measurement instrument of Trust in Municipal Government is adapted by the author based on the concept of trust in government (Schiffman, Thelen, \& Sherman, 2010), namely political cynicism and trust in government. Political cynicism is related with people's distrust of the government, such as people that felt neglected by the government, perceived lack of government protection for the people, government structure that is detrimental for the people, and others. Trust in Government is related with public believe toward the government, such as believe toward management of the government system, government concern toward the public, responsiveness to public needs, and others.

This scale has the following introduction: "I believe that ..." Examples of items from Trust in Government Scale are (unfavorable items): "The municipal government is not useful in solving the issues of its citizens"; "The municipal government does not care about the historical dimension of this city"; "The municipal government only deliver empty promises regarding health care of citizens"; "The municipal government lack response to public aspiration regarding transportation issues and traffic jam". Response options of the scale range from Strongly Disagree (score of 1) to Strongly Agree (score of 6). 
The role of psychology in enhancing public policy: Studies on political apathy and attachment to the city

Validity and reliability testing indicate that: measurement instrument of city attachment has an internal consistency index (Cronbach's Alpha) of 0.609 with construct validity index (corrected item-total correlations) ranging from 0.256 to 0.412 . There is a total of 8 items in this measurement instrument after reliability and validity testing. The measurement instrument of trust in government has a Cronbach's Alpha index of 0.742, with corrected item-total correlations ranging from 0.259 to 0.441 . There is a total of 16 items in the measurement instrument after reliability and validity testing. The measurement instrument of participation in urban music communities has a Cronbach's Alpha index of 0.888, with corrected item-total correlations ranging from 0.278 to 0.466. There is a total of 39 items in the measurement instrument after reliability and validity testing. Alpha Index of more than 0.6 and corrected item-total correlations above 0.25 indicates that the measurement instrument is reliable and valid.

\section{Results}

\subsection{Study 1}

Multiple linear regression analysis shows that $R^{2}=0.461, F(3,213)=59.949, p=0.000$. It is found that indecision dimension of decision fatigue $(\beta=0.255, p<0.01)$, and sense of citizenship $(\beta=-0.591, p<0.01)$ significantly predict political apathy (see Table 1). Meanwhile, impulsiveness dimension of decision fatigue $(\beta=$ $-0.017, p>0.05)$ cannot predict political apathy.

\section{Table 1}

Multiple Linear Regression Analysis Predicting Political Apathy $(n=214)$

\begin{tabular}{lcccc}
\hline \multicolumn{1}{c}{ Variable } & $B$ & $S E B$ & $\beta$ & $p$ \\
\hline Impulsiveness & -0.085 & 0.366 & -0.017 & 0.816 \\
Indecisiveness & 0.761 & 0.207 & 0.255 & 0.000 \\
Sense of citizenship & -1.064 & 0.099 & -0.591 & 0.000 \\
\hline Note. $R^{2}=0.461$ & & &
\end{tabular}

\subsection{Study 2}

Multiple linear regression analysis shows that $R^{2}=0.146, F(2,229)=19.425, p=0.000$. It is found that trust in municipal government $(\beta=-0.361, \mathrm{p}<0.01)$ significantly predict city attachment (see Table 2$)$. Meanwhile, participation in urban music community $(\beta=-0.114, p>0.05)$ cannot predict city attachment.

Table 2

Multiple Linear Regression Analysis Predicting City Attachment $(n=230)$

\begin{tabular}{lcccc}
\hline \multicolumn{1}{c}{ Variable } & $B$ & $S E B$ & $\beta$ & $p$ \\
\hline Trust in municipal government & -0.216 & 0.037 & -0.361 & 0.000 \\
Participation in urban music community & -0.033 & 0.017 & -0.114 & 0.064 \\
\hline Note. $R^{2}=0.146$ & & & &
\end{tabular}

\section{Discussion}

\subsection{Study 1}

Indecision as one dimension of decision fatigue is found to be able to predict political apathy in a positive direction. According to Hurm (2011), characteristics of indecisive person are mainly a sense of frustration or anxiety experience during the information collection process, where one found that he/she is lacking the knowledge regarding his/her social world and his/herself. Chiu (2007) formulates the main characteristic of indecision namely "the inability to mobilize the self to make a decision". Chiu also found 
psychological factors of indecision, namely decisional procrastination and fear of commitment. In other word, the individual understands the available options and what is at stake, but chose not to commit or not to participate. Decisional procrastination is a coping pattern of defensive avoidance where the individual handles the decision conflict by delaying the decision (Mann et al., 1997, as cited in Chiu, 2007). Fear of commitment is caused by pessimism or perception of negative outcomes that may occur after the decision has been made (such as, a wrong decision, disappointing others who are significant, loss of options, imperfect result, bad performance, and others). Viewing from the amount of efforts carried out by a person in decisional procrastination and fear of commitment, it is not surprising if it resulted in political apathy.

Based on characteristics and causes of indecision, the relation between indecision of decision fatigue and political apathy can be understood. Political apathy has several assumptions, such as those shown by Utschig (2000), namely conception of self that emphasize authenticity and monolithic conception of society that cannot be changed. Conception about authenticity of self is in line with the decisional procrastination because, in the decisional procrastination, individual understand the options and stakes at hand, but with a self-awareness that he/she is lacking knowledge and is frustrated. The problem is that psychologically, individual who let the self-stay authentic in indecision or decision fatigue and not "contaminated" by interaction will result in an individual who is apathetic toward politic because the core of politics is interacting selves. Utschig (2000, p. 385) states "This version of authenticity - that values the realization of an authentic self over values of community or interaction with others - can lead to political apathy in that it implicitly rejects the interconnection of individuals which is at the heart of political conviction." Furthermore, conception or belief about people that cannot be changed is in line with pessimism and fear of commitment. Fear of commitment is based on the perception that the result of one's political action will be negative or no result, and also resulting in political apathy. Political apathy according to Utschig (2000, p. 385) is based on the assumption "nothing, including political action or conviction, can make one whit of differences in the faces of such a monolith (impenetrable system)".

This study also found that impulsiveness as another dimension of decision fatigue is not able to predict political apathy. Impulsiveness is the tendency of an individual to avoid deliberateness as compared to of others who have the same ability (in decision making) prior to performing the act. "Impulsivity is the tendency to deliberate less than most people of equal ability before taking action" (Dickman, 1990, p. 95). However, according to Dickman (1990), there are two kinds of impulsivity namely functional impulsivity and dysfunctional impulsivity. The difference is as follows (Dickman, 1990, p. 95): "Dysfunctional impulsivity is the tendency to act with less forethought than most people of equal ability when this tendency is a source of difficulty. Functional impulsivity is the tendency to act with relatively little forethought when such style is optimal."

Essentially, Chiu (2007) stated that dysfunctional impulsivity is a source of difficulty, whereas functional impulsivity is a source of fluency. Both, according to Dickman, are not highly correlated each other and have different patterns in correlation with other psychological variables. Dysfunctional impulsivity correlates strongly with disorderliness and ignorance about hard facts during the decision-making process, whereas functional impulsivity is not correlated with them. Chiu $(2007$, p. 19) adds that dysfunctionally impulsive people: “... will have a greater urge to enact their decision behaviorally even when they are experiencing conflict with their available choices, and regardless of their awareness of preference and/or consequences related to the decision."

This study does not explicitly differentiate in measuring of functional impulsivity and dysfunctional impulsivity, hence does not find a correlation with political apathy. The author suspects that dysfunctional impulsivity relates or reflects apathy, whereas functional impulsivity relates with non-apathy because functional impulsivity can be transformed into decision-making strategies to be involved in political activities. Further study is advised to test this presumption.

Negative correlation between sense of citizenship and political apathy can be explained as follows: Sense of citizenship is an expression of the relationship between individual and political system (Sears, Huddy \& 
The role of psychology in enhancing public policy: Studies on political apathy and attachment to the city

Jervis, 2003). Citizenship contains rights, obligation, as well as responsibilities to communities and states (MacDonald, 1999; Morais \& Ogden, 2011; Muluk, 2010). Those matters will encourage deliberative democracy process (MacDonald, 1999). Thus, it is not surprising when sense of citizenship reduces political apathy.

\subsection{Study 2}

Negative correlation between trust in municipal government and attachment to the city can be explained as follows. Clark and Lee (2003) stated, "People may have little trust in government in general and still believed that something needs to be done about specific problems" (Clark \& Lee, 2003). This means that lack of trust in municipal government does not necessarily mean it will be followed with lack of attachment to the city. What might happen instead is lack of trust in municipal government is followed by attachment to the city. Why? Because, referring to Clark and Lee, community can positively act to solve the problem of the city even though there is a lack of trust in the municipal government. Mayer and Musswelier (2011) further refine this explanation; that distrust can spark creativity. The underlying mechanism is cognitive flexibility. Distrust is "beneficial" because it promotes the potential to improve one's creativity. Experimental empirical study has proved this issue. In other words, creative activities to make the city a more comfortable place to live by citizens' own ways, and as a consequence presents a perception of a higher attachment to the city, can in some ways be predicted by lack of trust in municipal government.

What about people who have a high trust in the government? High trust in municipal government does not necessarily followed with high attachment to the city. According to Clark and Lee (2003), trust in government can be "a constitutional consequence". More specifically, in everyday life, the expression by common people that can illustrate the issue is found in the following statement:

Do not always blame the government! Because the government has been trying to perform the obligations and duties, which is to create public welfare. If there is someone to blame, I am the one! Blame me for choosing the current government through the General Election! Blame me for paying my taxes on time to the government, so that money can be corrupted by Gayus and his companions! (Dwiputra, 2011).

For these people, while trust in government continue to exist (as a consequence of awareness that the municipal government is the result of their constitutional decision), attachment to the city occurs in the reverse direction. The expression in the last sentence above shows that people are aware of the corruption that occurs by a government official (Gayus). However, the first sentence quoted above, "The government has been trying to perform their obligations and duties", shows that the person also has trust in the government (in the constitutional context). This means that people or participants of the study living in the cities are actually living in tension or contradiction between two realities. How to explain these apparently conflicting relationships?

By referring to the thinking of Clark and Lee (2003), trust in government does not always have to be in line with a satisfaction with government performance. It may happen that to participants of this study; trust in government is high, but government performance is low (as revealed in public complaints) thus resulting in low attachment to the city. This issue can be the subject of further research because this study does not measure participant's satisfaction toward government performance. Why can trust toward government be high when its performance is low? Bierhoff and Bernd (2004) provide an explanation that is in line with the symptom of "optimistic bias" in social psychology. They reported their study's result, "An optimistic pattern was found: People are easily persuaded to form trust". People are easily persuaded to form trust, for instance, through government advertisement in mass media which form an impression management that the government is trustworthy. Bierhoff and Bernd (2004) revealed a number of qualities of parties that can bring trust; among others is that the party communicates that they are willing to cooperate for the common good. In this study, "other party" refers to the municipal government. This study has not confirmed whether the object of perception of public trust is the current municipal government (for example, in Jakarta: Jokowi and his officials, who is 
currently serving) or the past municipal government (for example, in Jakarta: Fauzi Bowo and his officials). This is so because when this study was initially conducted, Jokowi just served as Jakarta governor for only around six months. What is clear is that both conducted impression management through cooperative communication (for example: Munawwaroh, 2012).

Another explanation is provided by Segal (2003). He revealed his study results that the level of trust in government is instrumental. It means that as long as municipal government can fulfill the needs of the people (i.e. the participant of this study: people who are active in urban music community), then trust will be high. When associated with this study, support of municipal government toward the music community is something real. For example, in Jakarta, the support is represented through government feedback to Jakarta Arts Council and facilitation of the music communities' expression through Youth Night. Jokowi's expression when inaugurating the Jakarta Arts Council supports this argument: "Thus, the city can live if there is a balanced life, the art, not just economy. There are other aspects that must be build," said Jokowi after inaugurating new members of the Jakarta Arts Council at Balai Agung” (“Jokowi Lantik”, 2013).

However, as previously mentioned, government performance in the field of non-music is also thought to affect the lack of attachment to the city. Using the perspective of identification, described by Stets and Burke (2000), trust forms self-categorization or personal identity through the identification process. The object of identification in this case is the municipal government. Perhaps, the trust toward municipal government creates certain expectations. However, people has already too far conducted identification or modeling with the government acts, whereas the behavior of the municipal government might be interpreted as the one that is not attached to the city (for example through permit policies for building malls that kill off green spaces and others). As a consequence, the behavior of government becomes the public's object of identification. This may explain why when trust in government is high; the attachment to the city is low.

This study found that participation in activities of urban music community is not able to predict attachment to the city. The author hypothesized that participation may increase the attachment to the community, but it is not supported by empirical data. This means there is a distance between identity as a community member (for example in an urban music community) and identity as citizens of a city. A person who participates and becomes attached to urban music community does not necessarily have a high level of attachment and identification with the city. Gilchrist, Bowles, and Wetherell (2010) explain that there are several possible relationships between identity aspects within a person. One possible thing is "intersection", that is combination and modification between one's own identity. Identity as a consequence of participation and attachment to urban music community may have intersection with the level of attachment and identification with the city. However, intersection can be weak, strong or nonexistent.

Gilchrist et al. (2010, p. 26) proposed that civic engagement will be democratic if the object of attachment (in this study: the city) is inclusive and provide a possibility for people or groups with different identity, needs, and preferences to participate and integrate with the general decision making process. The absence of the predictive relationship between participation in activities of the music community and attachment to the city indicates the lack or absence of integration between community and city. In other words, by using the Woods's proposition (2006), self-formation as a citizen does not receive input from participation in and attachment with urban community. There is no coherent constructive narrative occurring between attachments with the community and attachment with the city.

\section{General Discussion, Conclusion and Suggestion}

This article posits that psychology is a partner of science of public policy based on the understanding that these disciplines include similar strong intention for public welfare. This research suggests that the understanding of individual's cognition and affection which develops in the citizen context, in this case sense of citizenship and attachment to the city can support public policy formulation to a more realistic policy and to a 
The role of psychology in enhancing public policy: Studies on political apathy and attachment to the city

policy which respect on the psychological dynamics. This research concludes that human's psychology should not be ignored. Moreover, it should be continuously monitored by the public policy makers since the public has their own logic in a certain place and time. It is indicated from the result and discussion of this research in which 3 out of 5 (or: $60 \%$ ) of the author's hypotheses are not supported by the empirical data.

In a way, the result of this research can be viewed either as a form of "public opinion" or as a "public discourse" since psychological reality of the public is captured from the bottom by a survey. Stimson, Mackuen, and Erikson (1995) proposed that public policy which is constructed by considering, anticipating and/or adopting public opinion and discourse is a "dynamic representation" phenomena which-although it is complex and requires self and institutional changes - can increase the efficacy of public policy implementation. Ha et al. (2009, p. 649) provides an example of a real case stating that when the government does not pay attention to public logic, the public condition in general will take a bad turn: "Korean government's inattention to public discourse and policy-making strategies is largely responsible for the difficulties it has experienced in recent years." The result of this research can be useful for politicians to win constituent heart. Thus, the public policy they took will be easy to be advocated by the public.

Subsequent studies need to integrate the cultural aspects in the research model which explains political behavior and the role of psychology in formulating public policy. Feldman (1990), for example, found that in Japan, cultural environment has a major impact in political behavior. Feldman wrote: "Japan's cultural heritage and traditional values and beliefs (which attach much importance to social deference), and the solidarity, dependency, and conflict-avoidance within the group greatly influence Japanese political behavior" (Feldman, 1990, p. 789). Wan, Tam, and Chiu (2010) found that in Hong Kong and the US, voting behavior was influenced by compatibility between public representations of a political party's culture and the personal values and beliefs of voters which identify themselves with that party.

Gastil, Braman, Kahan, and Slovic (2011) found that the cultural view is a better predictor for public political preference toward public policy compared to liberal self-identification. In those cases, culture becomes a heuristic that provide a network of meaning for public to interpret and deal with policy issues. Indonesia's situation, with its diverse local culture, makes it highly possible for organizing research which examines the influence of culture on public policy making and the perception, response, as well as negotiation of the public towards it. Operationally, culture can be treated as a variable which interacts with independent variables of Study 1 (sense of citizenship and decision fatigue) and Study 2 (participation in urban music community and trust in municipal government).

\section{References}

Abidin, S. Z. (2012). Public policy [Kebijakan publik ](2nd ed.). Jakarta: Salemba Humanika.

Abraham, J., \& Viatrie, I. E. (2013). Are creativity and attitude toward economics able to predict students' political participation? The mediating role of political efficacy among students in Malang, East Java [Apakah kreativitas dan sikap terhadap ilmu ekonomi meramalkan partisipasi politik mahasiswa? Peran mediasi efikasi politik pada mahasiswa di Malang, Jawa Timur]. MAKARA Seri Sosial Humaniora, 17(2), 109-125.

Ancok, D. (2004). Applied psychology: Analyzing the dynamics of human life [Psikologi terapan: Mengupas dinamika kehidupan umat manusia]. Yogyakarta: Darussalam.

Augenblick, N., \& Nicholson, S. (2012). Ballot position, choice fatigue, and voter behavior. Retrieved from http://faculty.haas.berkeley.edu/ned/Choice_Fatigue.pdf

BCCF. (2011). Review and photos of the talk show with Lewis Biggs @ Simpul space BCCF [Review \& foto kegiatan talk show bersama Lewis Biggs @ Simpul space BCCF]. Retrieved from http://bandungcreativecityforum.wordpress.com/2011/10/30/tulisan-singkat-foto-liputan-talk-show-bers ama-lewis-biggs-simpul-space-bccf/

Bierhoff, H-W., \& Bernd, V. (2004). The social psychology of trust with applications in the internet. Analyse und 
Anindya, S., Leolita, V., \& Abraham, J.

Kritik, 26(1), 48-62.

Brayfield, A. H. (1967). Psychology and public affairs. American Psychologist, 22(3), 182-186. http://dx.doi.org/10.1037/h0037762

Brokaw, L. (2011, August 31). Impulsive? Indecisive? You may have "decision fatigue". Retrieved from http://sloanreview.mit.edu/article/impulsive-indecisive-you-may-have-decision-fatigue/

Campbell, C., \& Jovchelovitch, S. (2000). Health, community and development: Towards a social psychology of participation. Journal of Community \& Applied Social Psychology, 10, 255-270. http://dx.doi.org/10.1002/1099-1298(200007/08)10:4<255::AID-CASP582>3.0.CO;2-M

Chiu, P. Y. (2007). A model of indecisiveness: The impact of psychological, demographic, decision specific and situational factors on indecisiveness. Unpublished dissertation, Graduate School of Applied and Professional Psychology of Rutgers, The State University of New Jersey.

Clark, J. R., \& Lee, D. R. (2003). Trust in government as a constitutional consequence. Journal of Private Enterprise, 18(2), 1-21.

Dickman, S. J. (1990). Functional and dysfunctional impulsivity: Personality and cognitive correlates. Personality and Individual Differences, 58(1), 95-102.

Dwiputra, A. (2011). Do not blame the Government ceaselessly; blame me [Jangan salahkan Pemerintah terus, salahkan saya]. Retrieved from http://sosok.kompasiana.com/2011/07/30/jangan-salahkan-pemerintah-terus-salahkan-saya-385015.html

Feldman, O. (1990). Political psychology in Japan. Political Psychology, 11(4), 787-804. http://dx.doi.org/10.2307/3791484

Ferrari, J. R., \& Pychyl, T. A. (2007). Regulating speed, accuracy and judgments by indecisives: Effects of frequent choices on self-regulation depletion. Personality and Individual Differences, 42, 777-787. http://dx.doi.org/10.1016/j.paid.2006.09.001

Fischhoff, B. (1990). Psychology and public policy: Tool or toolmaker. American Psychologist, 45(5), 647-653. http://dx.doi.org/10.1037/h0091626

Fuller, T. L., \& Fincham, F. D. (1995). Attachment style in married couples: Relation to current marital functioning, stability over time, and method. Personal Relationships, 2, 17-34. http://dx.doi.org/10.1111/j.1475-6811.1995.tb00075.x

Gardner, R. O. (2010). Introduction-Spaces of musical interaction: Scenes, subcultures, and communities. Studies in Symbolic Interaction, 35, 71-77. http://dx.doi.org/10.1108/S0163-2396(2010)0000035008

Gastil, J., Braman, D., Kahan, D., \& Slovic, P. (2011). The cultural orientation of mass political opinion. PS: Political Science and Politics, 44(4), 711-714. http://dx.doi.org/10.1017/S1049096511001326

Gilchrist, A., Bowles, M., \& Wetherell, M. (2010). Identities and social action: Connecting communities for a change. Economic \& Social Research Council, Community Development Foundation.

Gittins, R. (2012). Using psychology to improve economic policy. The Australian Economic Review, 45(3), 379-385. http://dx.doi.org/10.1111/j.1467-8462.2012.00689.x

Ha, Y., Joo, J., Kang, M., Lah, T. J., \& Jang, J. (2009). Social conflicts and policy-making in Korea: Interpretation of policy failures through a public discourse perspective. International Review of Administrative Sciences, 75, 649-664. http://dx.doi.org/10.1177/0020852309351447

Hardiman, F. B. (2009). City and the words: The shifting of the city's social meaning [Kota dan kata: Pergeseran makna sosial kota]. Paper presented at Studium Generale "Philosophy in the City", Goethe-Institut Jakarta \& Sekolah Tinggi Filsafat (STF) Driyarkara, 18 June 2009, Jakarta.

Heinowitz, A. E., Brown, K. R., Langsam, L. C., ...., \& Cash, R. E. (2012). Identifying perceived personal barriers to public policy advocacy within psychology. Professional Psychology: Research and Practice, 43(4), 372-378. http://dx.doi.org/10.1037/a0029161

Herry-Priyono, B. (2009). City and the wealth [Kota dan harta]. Paper presented at Studium Generale "Philosophy in the City", Goethe-Institut Jakarta \& Sekolah Tinggi Filsafat (STF) Driyarkara, 16 October 2009, Jakarta.

Hurm, B. V. (2011). Examining the differentiating factors predicting developmentally, moderately, and chronically indecisive. Unpublished dissertation, Purdue University, West Lafayette, Indiana. 
The role of psychology in enhancing public policy: Studies on political apathy and attachment to the city

Jokowi inaugurated the members of The Jakarta Arts Council [Jokowi lantik anggota Dewan Kesenian Jakarta]. (2013, 16 April). Suara Pembaruan. Retrieved from http://www.suarapembaruan.com/home/jokowi-lantik-anggota-dewan-kesenian-jakarta/33973

MacDonald, D. G. (1999). Implementation of programmes of deliberation and civic education to counter erosional effects of civic apathy upon liberal-democratic polities. MA Thesis, Faculty of Graduate Studies, The University of Western Ontario.

Magnis-Suseno, F. (2009). City and the works [Kota dan kerja]. Paper presented at Studium Generale "Philosophy in the City", Goethe-Institut Jakarta \& Sekolah Tinggi Filsafat (STF) Driyarkara, 19 February 2009, Jakarta.

Mayer, J., \& Musswelier, T. (2011). Suspicious spirits, flexible minds: when distrust enhances creativity. Journal of Personality and Social Psychology, 101(6), 1262-1277. http://dx.doi.org/10.1037/a0024407

McKnight, K. M., Sechrest, L., \& McKnight, P. E. (2005). Psychology, psychologists, and public policy. Annual Review of Clinical Psychology, 1, 557-576. http://dx.doi.org/10.1146/annurev.clinpsy.1.102803.144130

Morais, D. B., \& Ogden, A. C. (2011). Initial development and validation of the global citizenship scale. Journal of Studies in International Education, 15(5), 445-466. http://dx.doi.org/10.1177/1028315310375308

Muluk, H. (2010). Reviving the public: Perspective of political psychology. Inaugural address as Professor of Psychology [Menghidupkan kembali publik: Perspektif psikologi politik. Pidato pengukuhan sebagai Guru Besar Tetap Ilmu Psikologi]. Faculty of Psychology, University of Indonesia, Depok, 27 January 2010.

Munawwaroh. (2012). The plus and minus of Foke's and Jokowi's image making in the LSI's version [Plus minus pencitraan Foke vs Jokowi versi LSI]. Retrieved from http://www.tempo.co/read/news/2012/09/17/228429898/Plus-Minus-Pencitraan-Foke-vs-Jokowi-versi$\underline{\mathrm{LSI}}$

Munger, M. C. (2011). Persuasion, psychology, and public choice. Journal of Economic Behavior \& Organization, 80, 290-300. http://dx.doi.org/10.1016/j.jebo.2011.07.012

Nicholson, S. (2007). The effects of choice context on decision-making: An application to voter fatigue. Retrieved from http://www.sabanciuniv.edu/HaberlerDuyurular/Documents/DD20080129111757/nicholson.pdf

Nowotny, K. M., Fackler, J. L., Muschi, G., ...., \& Kotarba, J. A. (2010). Established Latino music scenes: Sense of place and the challenge of authenticity. Studies in Symbolic Interaction, 35, 29-50. http://dx.doi.org/10.1108/S0163-2396(2010)0000035006

Raymond, C. M., Brown, G., \& Weber, D. (2010). The measurement of place attachment: Personal, community, and environmental connections. Journal of Environmental Psychology, 30(4), 422-434. http://dx.doi.org/10.1016/j.jenvp.2010.08.002

Sarason, S. B. (1984). Community psychology and public policy: Missed opportunity. American Journal of Community Psychology, 12(2), 199-207. http://dx.doi.org/10.1007/BF00897043

Schiffman, L., Thelen, S. T., \& Sherman, E. (2010). Interpersonal and political trust: Modeling levels of citizens' trust. European Journal of Marketing, 44(3/4), 369-381. http://dx.doi.org/10.1108/03090561011020471

Schneider, C. J. (2009). Introduction: Music and identity. Studies in Symbolic Interaction, 35, 7-10. http://dx.doi.org/10.1108/S0163-2396(2010)0000035004

Sears, O. D., Huddy, L., \& Jervis, R. (2003). Oxford handbook of political psychology. New York: Oxford University Press.

Segal, J. T. (2003). Why Americans don't trust government and why they sometimes do: Trust in government in the United States from the 1960s to the present. Unpublished $\mathrm{PhD}$ dissertation, John Hopkins University, Baltimore, Maryland.

Sirgy, M. J. (2008). Philosophy, psychology, and public policy aspects of well-being all wrapped in one book designed to ruffle your feathers. Applied Research Quality Life, 3, 315-317. http://dx.doi.org/10.1007/s11482-009-9059-9

Stets, J. E., \& Burke, P. J. (2000). Identity theory and social identity theory. Social Psychology Quarterly, 63(3), 224-237. http://dx.doi.org/10.2307/2695870 
Anindya, S., Leolita, V., \& Abraham, J.

Stimson, J. A., Mackuen, M. B., \& Erikson, R. S. (1995). Dynamic representation. The American Political Science Review, 89(3), 543-565. http://dx.doi.org/10.2307/2082973

Strickland, T. (1996). Moving psychology toward (self) recognition as a public resource: The views of a congressman psychologist. In R. P . Lorion, I. Iscoe, P. H. DeLeon, \& G. R. Van den Bos (Eds.), Psychology and public policy: Balancing public service and professional need (pp. 369-389). Washington DC: American Psychological Association.

Supelli, K. (2009). City and the nature [Kota dan alam]. Paper presented at Studium Generale "Philosophy in the City", Goethe-Institut Jakarta \& Sekolah Tinggi Filsafat (STF) Driyarkara, 20 August 2009, Jakarta.

Sutrisno, M. (2009). City and the culture: Public space, its meeting point? [Kota dan budaya: Ruang publik, titik temunya?]. Paper presented at Studium Generale "Philosophy in the City", Goethe-Institut Jakarta \& Sekolah Tinggi Filsafat (STF) Driyarkara, 16 April 2009, Jakarta.

Thau, S., Crossley, C., Bennett, R. J., \& Sczesny, S. (2007). The relationship between trust, attachment, and antisocial work behaviors. Human Relations, 60(8), 1155-1179. http://dx.doi.org/10.1177/0018726707081658

Tierney, J. (2011). Do you suffer from decision fatigue? Retrieved from http://www.nytimes.com/2011/08/21/magazine/do-you-suffer-from-decision-fatigue.html?_r=3\&pagew anted=all\&

Tyas, T. H., Yuniarti, K. W., \& Kim, U. (2012). The role of trust in shaping mother-and-child relationship: Indigenous psychological analysis. International Journal of Research Studies in Psychology, 2(1), 3-12.

Utschig, A. S. (2000). Rethinking apathy: Political apathy from Kerouac to Coupland. Unpublished PhD dissertation, Department of Political Science, University of North Carlina at Chapel Hill.

Vohs, K. D., Baumeister, R. F., Schmeichel, B. J., ..., \& Tice, D. M. (2008). Making choices impairs subsequent self-control: A limited-resource account of decision making, self-regulation, and active initiative. Journal of Personality and Social Psychology, 94(5), 883-898. http://dx.doi.org/10.1037/0022-3514.94.5.883

Wan, C., Tam, K-P., \& Chiu, C-Y. (2010). Intersubjective cultural representations predicting behaviour: The case of political culture and voting. Asian Journal of Social Psychology, 13, 260-273. http://dx.doi.org/10.1111/j.1467-839X.2010.01318.x

Woods, N. E. (2006). Place attachment, place-identity, self-formation, and imagination: A narrative construction. Unpublished PhD dissertation, Graduate Faculty of the California School of Professional Psychology, Alliant International University.

Wunas, S. (2011). Humanistic city: The integration of land use and transport in suburban areas [Kota humanis: Integrasi guna lahan dan transportasi di wilayah suburban]. Surabaya: Brilian Internasional. 